\title{
Biologically Active Orbitides from the Euphorbiaceae Family
}

Authors

Suelem D. Ramalho ${ }^{1}$, Meri Emili F. Pinto ${ }^{1}$, Douglas Ferreira ${ }^{2}$, Vanderlan S. Bolzani ${ }^{1}$

Affiliations

1 Institute of Chemistry, São Paulo State University-UNESP, Araraquara-São Paulo, Brazil

2 Federal University of Western Bahia-UFOB, Luís Eduardo Magalhães-Bahia, Brazil

Key words

Euphorbiaceae, Croton, Jatropha, orbitides, cyclic peptides

received August 1, 2017

revised October 26, 2017

accepted October 30, 2017

Bibliography

DOI https://doi.org/10.1055/s-0043-122604

Published online November 23, 2017 | Planta Med 2018; 84:

558-567 @ Georg Thieme Verlag KG Stuttgart · New York |

ISSN 0032-0943

Correspondence

Prof. Dr. Vanderlan S. Bolzani

Institute of Chemistry, São Paulo State University-UNESP

Prof. Francisco Degni street, Araraquara-São Paulo,

14800-060, Brazil

Phone: + 551633019660 , Fax: + 551633222308

bolzaniv@iq.unesp.br
$\Theta$ Supporting information available online at http://www.thieme-connect.de/products

\section{ABSTRACT}

A comprehensive overview of natural orbitides isolated from Euphorbiaceae species and their most relevant biological activities are presented. Euphorbiaceae is a large and diverse family, which comprises about 300 genera, and is known as an important source of medicines and toxins. Several classes of secondary metabolites have been described for this taxon, however, orbitides have been broadly reported in Jatropha and Croton genera. Additionally, the latex is documented as the main source of orbitides in this family. Based on their structural and functional diversity, orbitides present a large variety of biological activities described as cytotoxicity, antimalarial, antibacterial, antifungal, enzymatic inhibition, and immunosuppressive, although the mechanism of action still needs to be further investigated. In recent years, the discovery of bioactive cyclic peptides from different sources has grown exponentially, making them promising molecules in the search for new drug leads. This review also highlights the attempts made by many researchers to organize the orbitides nomenclature and amino acid numbering, as well the important progress recently achieved in the biosynthetic study area.

\begin{tabular}{|c|c|}
\hline \multicolumn{2}{|c|}{ ABBREVIATIONS } \\
\hline AMPs & antimicrobial peptides \\
\hline CCK & cyclic cystine knot \\
\hline CIP & Cahn-Ingold-Prelog \\
\hline CPPs & cyclic peptides precursors \\
\hline IUPAC & $\begin{array}{l}\text { International Union of Pure and Applied } \\
\text { Chemistry }\end{array}$ \\
\hline OLP & oligopeptidase \\
\hline PCY & peptide cyclase \\
\hline PPlase & peptidyl-prolyl cis-trans isomerase \\
\hline RiPPs & $\begin{array}{l}\text { ribosomally synthesized and post-translationally } \\
\text { modified peptides }\end{array}$ \\
\hline SPPS & solid-phase peptide synthesis \\
\hline UniProt & Universal Protein Resource \\
\hline
\end{tabular}

\section{Introduction}

Nature continues to guide researchers in the discovery and development of novel drug leads [1]. Cyclic peptides are structurally diverse and are found in all kingdoms of life. Traditionally, they have been found in animals [2], fungi [3], bacteria [4], and marine [5] sources, although higher plants have recently been shown to be a rich source of cyclic peptides with peculiar composition, stability, and structural and functional diversity $[6,7]$. As a source of bioactive compounds, plants still play an important role in drug design and form the basis of many traditional medicines $[1,8]$. Based on their structure, plant-derived cyclic peptides are classified into cyclotides [9-12], orbitides [7, 13], and sunflower-derived peptides [14]. Their pharmacological activities, applications, and structures have been extensively investigated [7,15-19]. However, in addition to the obtained information, it is estimated that less than $1 \%$ of naturally occurring cyclic peptides have been discovered [20]. Orbitides constitute a class of natural cyclic peptides presenting a low molecular weight, ranging from 5 to 12 amino acids, ribosomally synthesized, with head-tail cyclization and a lack of 


\begin{tabular}{|ll}
\hline AM INO ACIDS \\
Ala & alanine \\
Arg & arginine \\
Asn & asparagine \\
Asp & aspartic acid \\
Cys & cysteine \\
Glu & glutamic acid \\
Gln & glutamine \\
Gly & glycine \\
His & histidine \\
Ile & isoleucine \\
Leu & leucine \\
Lys & lysine \\
Met & methionine \\
Phe & phenylalanine \\
Pro & proline \\
Ser & serine \\
Thr & threonine \\
Trp & tryptophan \\
Tyr & tyrosine \\
Val & valine \\
& \\
\hline
\end{tabular}

disulfide bonds $[17,18,21]$. Cys is reported to be the least abundant amino acid observed in orbitides [17].

Angiosperm families are characterized by the biosynthesis of a diversity of classes of secondary metabolites. According to a literature survey, the orbitides are described only in the families Annonaceae, Caryophyllaceae, Euphorbiaceae, Lamiaceae, Linaceae, Phytolaccaceae, Rutaceae, Schisandraceae, and Verbenaceae [17].

The Euphorbiaceae family, comprising approximately 300 genera, is recognized due to it's biosynthesizing of several classes of secondary metabolites, such as terpenoids, flavonoids, tannins, alkaloids, and steroids [22-24]. However, the members of this family are also described as a source of bioactive orbitides [13]. Even though Euphorbiaceae comprises most of the orbitides described in the literature, they were isolated from the genera Jatropha [25-34] and Croton [35-37]. The 1990s were considered the gold period of investigations of orbitides, with the discovery of several new molecules, thus demonstrating that the search for their mechanisms of action, structures, and biosynthesis needs to be expanded [7]. It should be noted that the majority of orbitides from Euphorbiaceae were isolated from the plant latex. Only a few compounds have been described in the leaves, stem bark, or aerial parts of the plant $[25,35]$.

In recent years, the discovery of bioactive cyclic peptides from different sources has grown exponentially, making them outstanding as the most promising molecules in the search for new drug leads $[15,16,19,38,39]$. The market for protein- and peptide-based drugs is over $\$ 40$ billion per year, and most of the available products are small peptides, ranging from 8 to 10 amino acid residues. These data reflect the number of papers found in the literature that primarily focus on peptide isolation, characterization, synthesis, pharmacological activities, and mechanism of action. It should be highlighted that over the years, more than 100 peptide drugs have reached the market, demonstrating the pharmaceutical potential of these compounds [19].

In this review, we discuss the biological activities, chemical synthesis, elucidation techniques, classification, and biosynthesis of bioactive orbitides isolated from the Euphorbiaceae family. All information shown was gathered via searching English papers from scientific databases including PubMed, Elsevier, Google Scholar, Scopus, Web of Science, Cybase, and SciFinder by using the key words Euphorbiaceae, cyclic peptides, and orbitides.

\section{Euphorbiaceae Family}

The Spurge family (Euphorbiaceae) is one of the most complex, largest and most diverse families of angiosperms and occurs in arid and semiarid environments $[40,41]$. It comprises approximately 300 genera and 8000 species, and it is established as an important source of medicines and toxins [42-44]. This family occurs mainly in the tropics, with the majority of the species in tropical and subtropical areas of Africa and the Americas. As might be expected from such a large and diverse family, there is a vast amount of information on its ethnomedical use, phytochemical investigations, and bioactive constituents. Williamson and Hooper [45] reported the use of Euphorbia polycarpa, Euphorbia hirta, and Acalypha indica L. for the treatment of different diseases in Ayurvedic medicine. In Chinese medicine, Lai and co-authors [46] reported 33 other species belonging to 17 genera of Euphorbiaceae used in herbal medicine. Among them, 17 species were used to treat snakebites, following the principle of "combat toxins with toxins". Several species are grown as ornamental plants (Euphorbia milli, Euphorbia tirucalli, Euphorbia obesa, and Euphorbia pulcherrima), and many others are of considerable economic importance, such as cassava (Manihot esculenta), the castor oil plant (Ricinus communis L.), the rubber tree (Hevea brasiliensis Willd. Ex. A. Juss), and a biodiesel source (Jatropha curcas L.) [42]. As several species within the Euphorbiaceae family contain toxic compounds, some plants are usually described in the literature as poisonous, especially those from the Jatropha [43] and Euphorbia genera, which might induce dermatitis. Phorbol esters and curcins are described in the literature as the most toxic components found in J. curcas L. and exhibit toxicity to many species, including microorganisms, animals, and humans [47]. Many plants have oleaginous seeds, may contain latex, and provide a source of rubber $[24,40]$. Latex is described as a complex mixture of peptides, enzymes, triterpenoids, diterpenoids, amino acids, and other compounds. Among the Euphorbiaceae family, latex is found primarily in members of the subfamilies Crotonoideae and Euphorbioideae, but is generally lacking in the Phyllanthoideae, Oldfieldioideae, and Acalyphoide subfamilies [24].

The Euphorbiaceae family presents a large variety of secondary metabolites, and the major types include alkaloids [23], triterpenoids $[48,49]$, flavonoids (both $C$ - and $O$-glycosides) $[49,50]$, diterpenoids [23], tannins, and peptides (cyclic and linear) [13, 24, 48]. According to the literature, all orbitides isolated from Euphorbiaceae to date consist exclusively of L-amino acids. The D-isomers are not commonly available from natural sources and are usually obtained by synthetic approaches [51]. 


\section{Classification}

The IUPAC provides rigorous recommendations for the nomenclature of linear peptides, although many attempts have been made recently by several researchers to organize and clarify the orbitides nomenclature [20]. In 2006, Tan and Zhou [7] reviewed and classified a range of plant-derived cyclic peptides into two classes, five subclasses, and eight types based on their chemical structure and family origin. Initially, the classification of these small natural cyclic peptides as Caryophyllaceae-type cyclopeptides (type VI) was based on phytochemical studies of Caryophyllaceae species. It was believed that small cyclopeptides were characteristic components of Caryophyllaceae plants [7]. In general, this nomenclature was based on the botanical families, leading to an unclear generalization. As demonstrated, naming a group as "Caryophyllaceae-type" or "Rubiaceae-type" leads to the conclusion that all the peptides described in this botanical family occur exclusively in this taxon, which is not true [18]. Thus, in 2013, Arnison and co-authors [17] published a review on RiPPs and proposed the name "orbitide" to replace the older designation "Caryophyllaceae-type cyclopeptides". In fact, RiPPs comprise a large group of natural peptides that are classified into subfamilies according to their biosynthetic pathway and the diversity of structural scaffolds. Caryophyllaceae-type homomonocyclopeptides, orbitides, and cyclotides are defined as RiPPs. In a general way, they can occur in many taxa and are genetically encoded and synthesized as precursor proteins [17, 52]. Additionally, according to Arnison and co-authors [17], it is too early to classify the various types of orbitides when only a few examples are reported in the literature. Recently, in 2015, Shim and co-authors [21], considering the disarray in the nomenclature of type VI cyclic peptides, proposed a new systematic naming system that reflects the taxonomic name of the species and a numbering system that enables systematic representation of the amino acid residues and modifications. According to the authors, this proposed nomenclature was based on IUPAC, UniProt, and the review published by Arnison and co-authors [17]. Following the instructions, the orbitide name should start with [1-\#-N $\alpha \mathrm{C}$ ], which refers to the linkage between amino acid 1 and "\#" through the $\alpha$-amino group that is an N-C cyclization of the core peptide. Then add [\#-Xaa, \#-Xaa], which refers to the modifications and specifies the position and type of modified amino acid(s). A comma must be used to separate multiple posttranslational modifications. In the sequence, add the taxonomic name abbreviation to identify the origin of the orbitide, which is based on the first three letters of the genus and the first two letters of the species name. Then add the common suffix (-orb) for orbitide. Finally, add the amino acid residue numbering (\#) that begins at the $\mathrm{N}$-terminal-most amino acid residue, based on the DNA sequence. As demonstrated in this review, papers published after this date (2015) describing the isolation of new orbitides started to adopt this nomenclature suggested by Shim and co-authors [21]. The use of this taxonomic nomenclature system allows the differentiation of orbitides with sequence diversity from closely related species.

Orbitides are described as small N-to-C terminal intramolecularly cyclized peptides from plants that do not have disulfide bonds, ranging from 5 to 12 amino acid residues. In contrast, cyclotides (type VIII) are natural peptides comprising 28-37 amino acids, which are cyclized by both the fusion of the terminal amino and cysteine double bonds, thus containing three conserved disulfide bonds, known as a CCK [7,9-11]. It was noticed that many amino acid residues might be underrepresented in orbitides. Cys is the least abundant amino acid observed, and some other residues such as Asp and Glu, their amides Asn and Gln, basic residues Lys and Arg, and His are also rare. Orbitides are found in higher plants but not in every taxon. So far, Annonaceae, Caryophyllaceae, Euphorbiaceae, Lamiaceae, Linaceae, Phytolaccaceae, Rutaceae, Schisandraceae, and Verbenaceae are the plant families described in the literature as containing orbitides [17].

Based on the discussion of cyclic peptide nomenclature and classification, a task group was recently designed by IUPAC to propose guidelines for homodetic cyclic peptides and specify amino acid priority for consistent numbering. IUPAC defines homodetic peptides as "cyclic peptides in which the rings consist only of amino acid residues in eupeptide linkage". The amino acid numbering of peptides can be determined by various methods such as mass spectrum sequencing, alphabet, gene sequencing, and CIP rules. According to Craik and co-authors [20], the CIP system is unequivocal and can be generally applied to proteinogenic, nonproteinogenic, and unnatural amino acids. In the CIP rules, the priority of the amino acids is assigned by comparing the atom's atomic number. A table containing the priority ranking of the amino acids can be found in the mentioned paper [20], and according this rule, proline takes the highest position, as it is the only amino acid that contains a secondary amine. The list of the 21 proteinogenic amino acids in the CIP priority is described as: Pro, Sec, Cys, Thr, Ser, Ile, Val, Met, Asp, Asn, His, Trp, Tyr, Phe, Leu, Glu, Gln, Arg, Lys, Ala, and Gly. Following this procedure, first identify the highestranking amino acid. Then, in case of duplicate amino acids, the next one on the C-terminal is compared. Finally, number the remaining amino acids from the $\mathrm{N}$-terminal to $\mathrm{C}$-terminal. Also, according to this rule, an $R$ amino acid presents higher priority over its $S$ isomer. As this system is not a formal IUPAC recommendation, the task group encourages further discussion and feedback from the scientific community [20]. In this review, compounds were numbered according to the CIP rules.

\section{Biosynthesis}

Understanding the biosynthetic mechanism is a challenge for all classes of peptides [53]. Not all of them are completely understood; sometimes the exact mechanism still remains unclear and needs to be further investigated. Regarding the biosynthesis of cyclic peptides from plants, the cyclotides present the bestunderstood pathway so far.

Based on their origins and biosynthetic pathways, in general, peptides can be organized into three groups: ribosomal, nonribosomal, and protein derivatives. Ribosomally synthesized peptides (RiPPs) are products of gene expression in which the amino acids are attached to one another during mRNA translation. The main classes of ribosomally synthesized cyclic plant peptides are the cyclotides, the SFTI-like peptides, also recognized as PawS-derived peptides (PDPs), and the orbitides [17].

Both orbitides and cyclotides differ greatly in arrangement and sequence $[17,54,55]$. Unlike cyclotides, orbitides have no disulfide bond, have a high proportion of hydrophobic residues, and 
are processed in two steps involving two separate enzymes: cleavage by an oligopeptidase (OLP) and cyclization by a PCY defined as a serine protease-like enzyme $[16,54,56]$. According to some assays with seed extracts using synthetic peptide substrates, orbitides from Saponaria vaccaria are first ribosomally synthesized as linear precursors (32-amino acid linear precursor), termed presegetalin A1 [54, 57]. Further, biochemical assays were carried out in S. vaccaria seed extracts to determine the enzymes involved in cyclic peptide formation in Caryophyllaceae. The first enzyme from S. vaccaria is OLP1, a serine protease that recognizes and cleaves the sequence corresponding to the junction between the N-terminal region and the incipient cyclic peptide sequence. The OLP1 cleaves the first 15 amino acids to yield a product containing an $\mathrm{N}$-terminal glycine (presegetalin A1 [14-32]) [56]. A second enzyme (PCY1) acts on this product to excise the linear C-terminal's 13 residues (presegetalin A1 [20-32]), with the concomitant macrocyclization of the remaining $\mathrm{N}$-terminal's six residues to yield the $c$ (Gly-Val-Pro-Val-Trp-Ala) segetalin A product. The biosynthesis of orbitides, as well as other RiPPs such as cyclotides, commonly uses convergent strategies based on Ser proteases that can catalyze the formation of a cyclic product via transamidation rather than a linear product via hydrolysis [56]. Biosynthetic studies were also conducted on the Citrus genus (Rutaceae), and the obtained data were consistent with the ribosome-dependent biosynthesis of orbitides via CPPs, which confirmed the role of the corresponding genes and provided evidence for the genes encoding CPPs [57].

Orbitides are generally derived from proteinogenic amino acids. Prior to 2011, very little was known about the biosynthesis of the orbitides and whether ribosomes were involved or not [57]. Recently, they started to be better understood once many aspects of RiPP biosynthesis and new insights were investigated [52]. The obtained data already described for systems such as Caryophyllaceae (S. vaccaria, Dianthus caryophyllus) and Rutaceae (Citrus spp.) are consistent and likely to provide further general insights into the mechanisms of enzyme activation and orbitide biosynthesis [57]. In 2011, the whole genome of J. curcas L. was sequenced, thus generating information for future research for this species and related plants. It was obtained using a strategy that combines the Sanger method and the new-generation multiplex sequencing methods. Also, when compared with genes from other plant species, it was indicated that $4 \%$ of genes are conserved specifically in the Euphorbiaceae family [58]. Finally, future efforts to obtain a better understanding of the biosynthetic pathway, genomic sequences, and the enzymes involved in RiPPs will contribute to the development and discovery of novel peptides with potential pharmaceutical and biotechnological applications [52, 54-56].

\section{Peptides from the Croton Genus}

Croton is a large genus from the Euphorbiaceae family comprising approximately 1300 species of trees, herbs, and shrubs commonly distributed in tropical and subtropical regions [23]. The seeds, roots, volatile oil, leaves, and stem bark are reported to contain several secondary metabolites [23] such as diterpenoids [59-62], triterpenoids, steroids, alkaloids, lignoids, proanthocyanidins, and flavonoids [37]. Some Croton species may contain latex, which is usually viscous and red colored [23]. Traditionally, the red sap, popularly known as dragon's blood or "sangre de gadro", is collected by cuts on the bark surface of several Croton species (Croton lechleri, Croton palanostigma, Croton draconoides, and Croton urucurana Baill.) and used by indigenous Amazon cultures and many others as a traditional medicine to promote wound healing [63, 64]. The Croton species are frequently associated with popular medicines for gastrointestinal ulcers and cancer, cicatrizants, and anti-inflammatory therapies $[65,66]$, and are reported to have a wide range of pharmacological properties such as mutagenic, apoptosis, antioxidant, antitumor, cytotoxic, and antiproliferative activity [23,65-69]. Cyclic peptides (orbitides) [35-37] (Table S1, Supporting Information) and some linear peptides [22] isolated from the Croton species have been described in the literature.

Studies on the latex of Croton gossypiifolius Vahl. led to the isolation of a cyclic nonapeptide named crotogossamide (1). This species was collected in Trinidad and Tobago but also occurs in Colombia, Venezuela, Mexico, and Martinique. Crotogossamide (1) was obtained as white crystals, and the amino acid sequence was determined to be cyclo(-Ser ${ }^{1}-$ Gly $^{2}-$ Leu $^{3}-$ Asn $^{4}$-Gly ${ }^{5}-1 e^{6}-$ Phe $^{7}-$ Gly $^{8}$ Ala $^{9}$-) [37]. C. urucurana Baill. is one of the dragon's blood species mentioned above $[36,63,64]$ and is commonly found in midwestern Brazil (Cerrado and Pantanal biomes). Examining the red latex of $C$. urucurana Baill. led to the isolation of an orbitide named [1-9$\mathrm{N} \alpha \mathrm{C}$ ]-crourorb $\mathrm{A} 1$ (2), a cyclic nonapeptide with an amino acid sequence defined as cyclo $\left(-\mathrm{Ser}^{1}\right.$-Leu $^{2}-\mathrm{Gly}^{3}$-Ala ${ }^{4}-\mathrm{Phe}^{5}$-Gly ${ }^{6}$-Asn ${ }^{7}-$ Leu $^{8}$ Gly ${ }^{9}$-) [36]. The proposed orbitide name for this compound followed the systematic nomenclature recently suggested by Shim and co-authors [21]. From whole plant material of Croton sparsiflorus Morong, a shrub found in Asia and South America, a cyclic nonapeptide named crotosparsamide (3) was isolated ( $\bullet$ Fig. 1). Crotosparsamide was obtained as white crystals, and the amino acid sequence was determined to be cyclo(-Val ${ }^{1}-\mathrm{Asn}^{2}-\mathrm{Gly}^{3}$-Ala ${ }^{4}$ Phe ${ }^{5}$-Gly ${ }^{6}$-Leu $^{7}$-Leu ${ }^{8}$-Gly ${ }^{9}$-) [35]. According to the literature data, all orbitides isolated from Croton species so far were defined as nonapeptides, and the absolute configurations of the amino acids were shown to be all $\mathrm{L}$, thus highlighting the biosynthetic pathway.

In addition to the cyclic peptides already described, two linear peptides were isolated from the aerial parts of Croton hieronymi Griseb., a plant native to northwestern Argentina [22]. Compound 4 was described as the peptide derivative aurentiamide acetate, and according to Catalan and co-workers [22], it was previously found in Aspergillus species, two algae, and some higher plants. The other compound was a new linear peptide derivative named N-benzoylphenylalaninyl-N-benzoylphenyl-alaninate (5), which differed from compound 4 in that the left half was esterified by N-benzoylphenylalaninol and a second benzamide functionality was present. It should be highlighted that compounds of this type are rare and have not previously been found in Croton species [22] ( $\bullet$ Fig. 2).

\section{Peptides from the Jatropha Genus}

The genus Jatropha comprises 170 species of woody trees, shrubs, and subshrubs distributed in tropical and subtropical countries. The name Jatropha derives from the Greek word jatrós, which means doctor, and the word trophé, which means food, thus implying the medicinal uses of these plants since ancient times [13, 


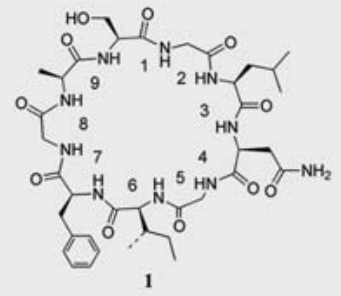

1

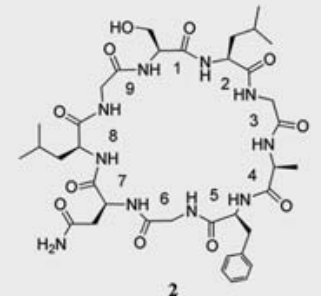

2

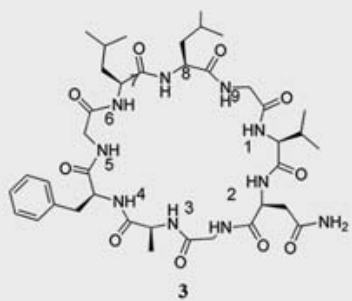

- Fig. 1 The structures of orbitides (1-3) from Croton species.

70]. Currently, Jatropha species are widely used as medicinal plants in several countries from Asia, Latin America, and Africa, even considering the toxicity of different parts of the plant [13, $43,71,72]$. They are commonly known for their popular uses for purgative, anti-allergic, wound healing, and anti-inflammatory effects [13]. Experimental studies described in the literature reveal antimicrobial, antineoplastic, wound healing, and hypotensive activities $[13,71]$. In the past two decades, studies on Jatropha seed oil, especially J. curcas L. and Jatropha gossypiifolia L., for biofuel have drawn attention, thus resulting in industrial-scale cultivation and making Jatropha species prospective high-quality biodiesel yielding crops $[43,71,73]$.

Phytochemical studies on Jatropha plants led to the isolation of several chemical constituents [71,72] such as alkaloids, triterpenoids, diterpenoids, sesquiterpenoids, flavonoids, coumarins, lignans, phorbol esters, phytosterols, and cyclic peptides. The Jatropha genus is characterized by the abundant production of latex, which is watery to white and contains saponin, resin, peptides, tannin, wax, and enzymes [70,71]. A protease named curcain was obtained from the latex of J. curcas L. and reported to have wound healing activity in mice $[70,74]$. The majority of cyclic peptides from Jatropha species were isolated from the latex, except for Jatropha ribifolia (Pohl) Baill. [25].

Investigations on the latex of J. curcas L., which is commonly known as a medicinal plant $[70,75]$, led to the isolation of three orbitides named curcacycline A (6) [29], curcacycline B (7) [30], and jatrophidin I [28] (8). Curcacycline A (6) is an octapeptide that was first isolated from an Indonesian plant, and its amino acid sequence was determined to be cyclo $\left(-\mathrm{Thr}^{1}-\mathrm{Val}^{2}\right.$-Leu ${ }^{3}$-Leu ${ }^{4}$-Gly ${ }^{5}$ Leu $^{6}$-Leu $^{7}-$ Gly $^{8}-$ ) [29]. The structure of curcacycline B (7), a nonapeptide, was determined to be cyclo(-Pro ${ }^{7}-I_{e}^{2}-$ Leu $^{3}-$ Leu $^{4}-G_{1}{ }^{5}-I l e^{6}-$ Leu $^{7}-$ Gly $^{8}-$ Ser $^{9}-$ ), and the plant was obtained from Senegal [30]. Later, in 2012, Insanu and co-workers [76] applied a synthetic approach to confirm the structures of curcacycline A (6) and B (7), and also applied new pharmacological insights into these orbitides. Jatrophidin I (8) was isolated from a Brazilian plant, and the amino acid sequence was determined to be cyclo(-Pro ${ }^{1}-\mathrm{Gly}^{2}-\mathrm{Leu}^{3}$ Leu $^{4}$-Asn ${ }^{5}$ Leu $^{6}-$ Trp $^{7}$-Gly ${ }^{8}$-). This compound contains an asparagine residue, which is not very common in cyclic peptides from plants. It was tested for some biological activities but was demonstrated to be inactive in antimalarial, antifungal, and antioxidant assays [28]. The cyclic octapeptide named ribifolin (9), an amorphous white solid, was isolated from the aerial parts of J. ribifolia (Pohl) Baill. This plant was collected in the semiarid northeastern
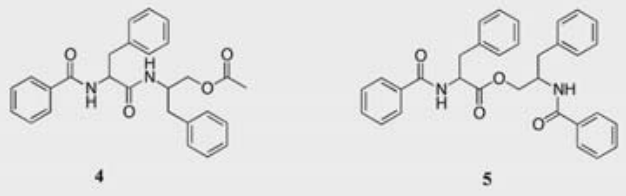

- Fig. 2 The structures of linear peptides $(4,5)$ from C. hieronymi Griseb.

region of Brazil, and the sequence of the orbitide was determined

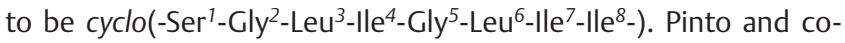
workers [25] also described the synthesis of the linear ribifolin analogue by an SPPS, which was used in further studies to determine the role of cyclization in some bioactivity assays. Studies on the latex of J. gossypiifolia L. led to the isolation of two orbitides, one heptapeptide and one octapeptide, named cyclogossine A (10) [77] and cyclogossine B (11) [31], respectively. The structure of cyclogossine $A(10)$ was determined to be cyclo(-Thr ${ }^{1}-$ Ala $^{2}-$ Leu $^{3}$ $\mathrm{Val}^{4}$-Gly ${ }^{5}$-Leu $^{6}-$ Trp $^{7}$-), and it was isolated from a plant collected in Indonesia [77]. Cyclogossine B (11) was isolated from a plant from Senegal, and the amino acid sequence was determined to be cyclo (-Ile -Leu $^{2}-$ Gly $^{3}-$ Gly $^{4}-$ Trp $^{5}-$ Leu $^{6}-$ Ala $^{7}-\mathrm{Ala}^{8}$-) [31] (• Fig. 3).

A study on the latex of Jatropha pohliana ssp. molissima led to the isolation of two cyclic heptapeptides, pohlianins $A(12)$ and $B(13)$, and one cyclic octapeptide, pohlianin C (14) [26]. This plant was collected in the semiarid northeastern region of Brazil. The amino acid sequence of pohlianin $A(12)$ was determined to be cyclo(-Pro ${ }^{1}$ -

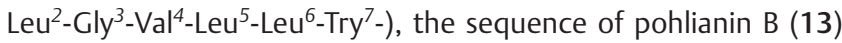

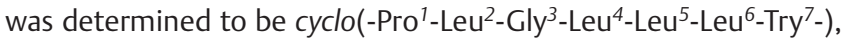
and the sequence of pohlianin $C(14)$ was determined to be cyclo

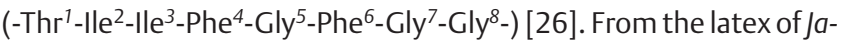
tropha chevalieri Beille, a small shrub collected in Senegal, researchers obtained three orbitides named chevalierins $A(15)$ and $B(16)$, two cyclic octapeptides, and chevalierin $C$ (17), a cyclic nonapeptide [34]. Locally, in folk medicine, the latex of this plant is used to treat infected wounds. The structure of chevalierin $A(15)$ was determined to be cyclo(-Pro ${ }^{1}-\| e^{2}-$ Leu $^{3}-$ Ala $^{4}-\| e^{5}-$ Met $^{6}-$ Gly $^{7}-\| e^{8}-$ ), and the sequence of chevalierin $C$ (17) was determined to be cyclo (-Thr ${ }^{1}-\| e^{2}-$ Phe $^{3}-$ Asp $^{4}-\| e^{5}-$ Phe $^{6}-$ Gly $^{7}-$ Ala $^{8}-$ Tyr $^{9}$-). Chevalierin B (16) was found to be very similar and to have the same amino acid sequence as chevalierin A (15), and the only difference is the additional oxygen atom, suggesting the presence of methionine sulfox- 

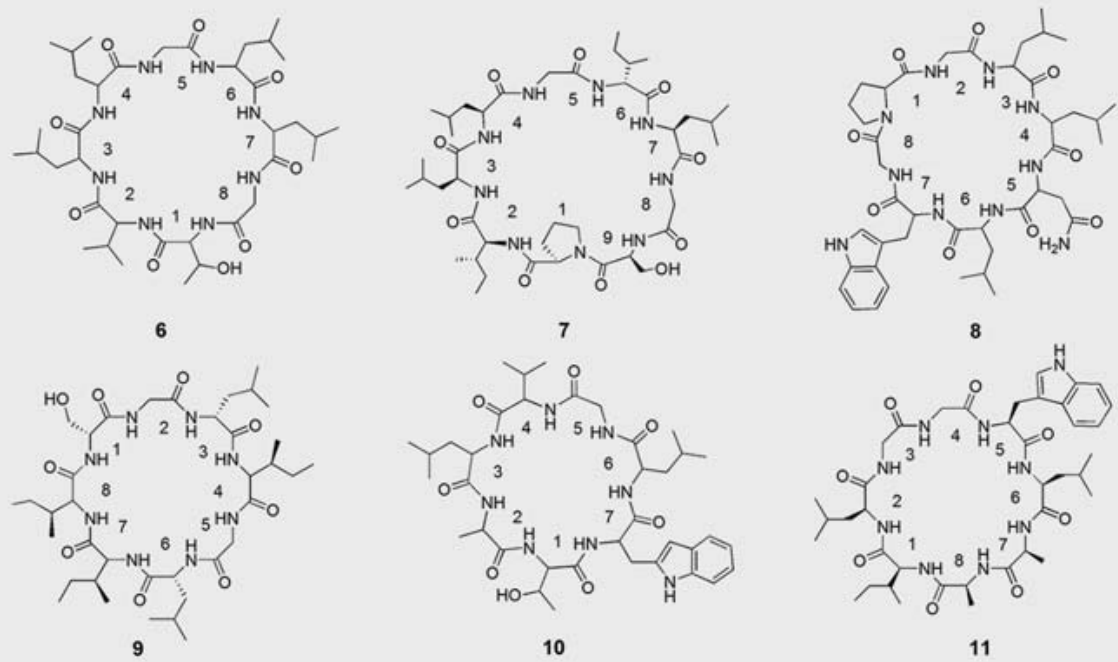

10

- Fig. 3 The structures of orbitides (6-11) from Jatropha species.
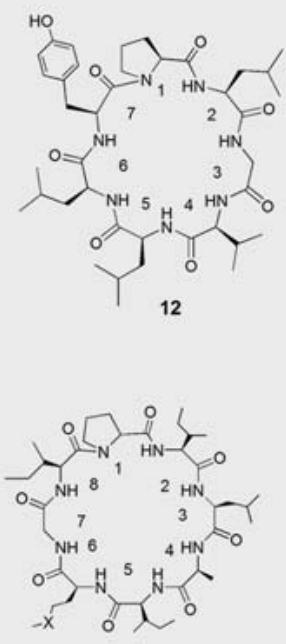

$15 X: S$

$16 X: S=0$

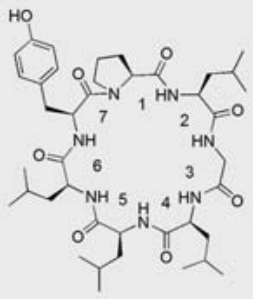

13

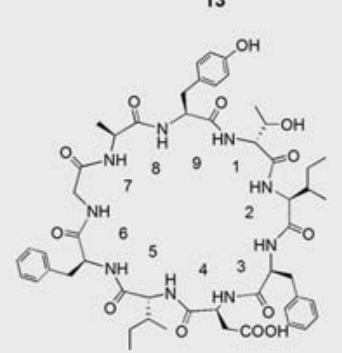

17

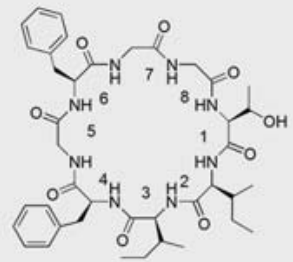

14

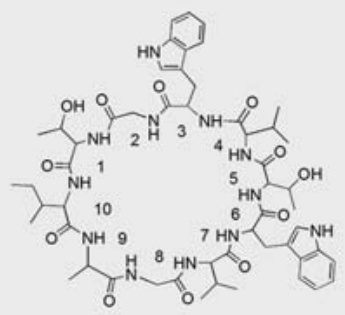

18

- Fig. 4 The structures of orbitides (12-18) from Jatropha species.

ide (Mso) instead of methionine (Met). Thus, the structure of chevalierin B (16) was described as cyclo(-Pro ${ }^{7}-1 \mathrm{e}^{2}-\mathrm{Leu}^{3}-\mathrm{Ala}^{4}-\| \mathrm{e}^{5}-\mathrm{Mso}^{6}$ $\mathrm{Gly}^{7}-\mathrm{Ile}^{8}$-) ( Fig. 4). They also described the synthesis of the chevalierins' linear precursors using a solid-phase technique [34].

From the latex of Jatropha multifida L. collected in Indonesia from leaf stalks, two orbitides, named labaditin (18) [32], a cyclic decapeptide, and biobollein (19) [78], a cyclic nonapeptide, have been reported. Its latex is commonly used in folk medicine for the treatment of infected wounds and skin infections. The structure of labaditin (18) was determined to be cyclo(-Thr ${ }^{1}-\mathrm{Ile}^{2}-\mathrm{Ala}^{3}-\mathrm{Gly}{ }^{4}$ $\left.\mathrm{Val}^{5}-\mathrm{Trp}^{6}-\mathrm{Thr}^{7}-\mathrm{Val}^{8}-\mathrm{Trp}^{9}-\mathrm{Gly}^{10}{ }^{-}\right)$and according to Kosasi and co-authors [32], it was the first time that a cyclic decapeptide was documented in higher plants. The sequence of biobollein (19) was determined to be cyclo(-Ser ${ }^{1}-\| e^{2}$-Leu $^{3}$-Gly ${ }^{4}$-Leu ${ }^{5}$-Gly ${ }^{6}-T_{r}{ }^{7}$ Ala ${ }^{8}-\mathrm{Ala}^{9}-$ ) [78]. Examination of Jatropha mahafalensis Jum. \& $\mathrm{H}$. Perrier, a tree endemic to Madagascar and also used to treat infected wounds in traditional medicine, led to the isolation of two cyclic heptapeptides named mahafacyclin A (20) [79] and mahafacyclin B (21) [33]. The amino acid sequence of mahafacyclin A

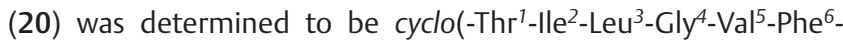
Gly ${ }^{7}$-), and according to the authors it was the first natural cyclic heptapeptide without proline to present the $\beta$-bulge characteristics [79]. It should be noted that the $\beta$-motif observed in cyclic heptapeptides usually contains at least one proline residue [26, 


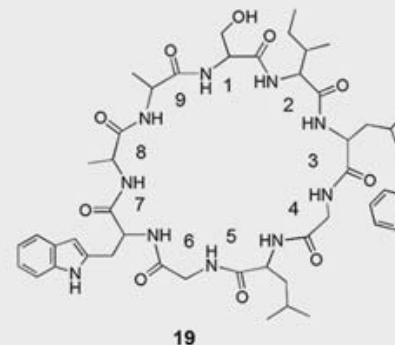

19

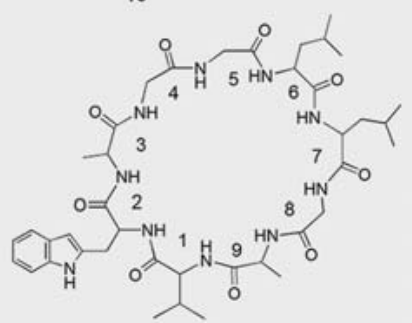

22

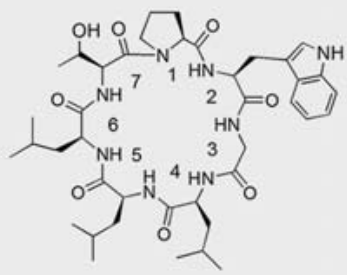

24

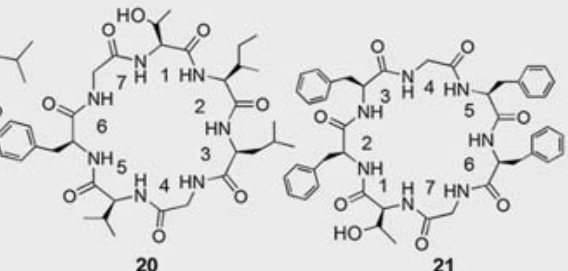

20

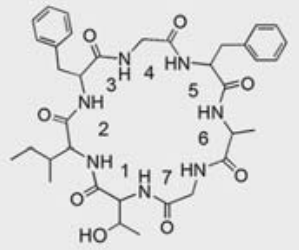

23

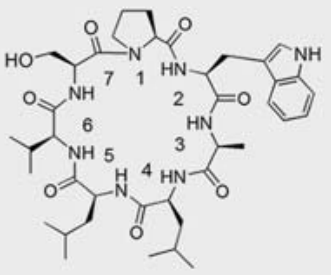

25

- Fig. 5 The structures of orbitides (19-25) from Jatropha species.

33, 79]. Mahafacyclin B (21) was identified as a minor component of J. mahafalensis Jum. \& H. Perrier latex, and the structure was determined to be cyclo(-Thr ${ }^{7}-\mathrm{Phe}^{2}-\mathrm{Phe}^{3}-\mathrm{Gly}^{4}-\mathrm{Phe}^{5}-\mathrm{Phe}^{6}-\mathrm{Gly}{ }^{7}-$ ), highlighted by the presence of four phenylalanine residues. The linear precursor of mahafacyclin B (21) was synthesized by a solution phase method [33]. Research on the latex of Jatropha podagrica Hook, a plant collected in Kenya, led to the isolation of two orbitides, podacycline $A$ (22), a cyclic nonapeptide, and podacycline $B$ (23), a cyclic heptapeptide. The structure of podacycline A (22) was determined to be cyclo(-Val ${ }^{1}-$ TrP $^{2}-$ Ala $^{3}$-Gly ${ }^{4}-$ Gly $^{5}-$ Leu $^{6}-$ Leu $^{7}$ $\mathrm{Gly}^{8}-\mathrm{Ala}^{9}-$ ), and the structure of podacycline B (23) was deter-

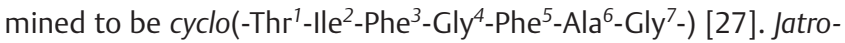
pha integerrima Jacq. was collected in Thailand, and two cyclic heptapeptides, integerrimides A (24) and B (25), were isolated from the latex. The orbitide integerrimide $A$ (24) was obtained as a colorless solid and identified as cyclo(-Pro ${ }^{1}-$ TrP $^{2}-$ Gly $^{3}-$ Leu $^{4}-$ Leu $^{5}$ Leu $^{6}-\mathrm{Thr}^{7}$-). Integerrimide B (25) was obtained as colorless needles and identified as cyclo(-Pro ${ }^{7}-$ TrP $^{2}-$ Ala $^{3}$-Leu ${ }^{4}-$ Leu $^{5}-$ Val $^{6}-$ Ser $^{7}$-) [80] ( Fig. 5).

In addition to the presence of cyclic peptides in the latex of J. curcas L., an investigation of the seeds led to the isolation of a new linear peptide named PII-C, consisting of 14 amino acid residues and having a molecular mass of $1341.58 \mathrm{Da}[\mathrm{M}+\mathrm{H}]^{+}$. The amino acid sequence was found to be Ala-Pro-Thr-Leu-Ser-GlyGly-Ser-Val-Pro-Arg-Asp-Ala-Asp [81].
It should be mentioned that all orbitides already described in the literature from Jatropha species have an L-configuration, a low amino acid complexity, and a high proportion of hydrophobic amino acids, which is commonly noticed in cyclic peptides isolated from the Caryophyllaceae group (Table S1, Supporting Information) $[17,18]$. Concerning cyclic peptides, we can assume that the Jatropha genus has been investigated in greater detail than the other representative genera of the Euphorbiaceae family.

\section{Peptides from Other Genera (Euphorbiaceae Family)}

In addition to the orbitides predominantly described in Croton and Jatropha species, some other genera from the Euphorbiaceae family have also been identified as sources of peptides and derivatives. Those peptides are usually differentiated from orbitides by the presence of disulfide bonds, a lack of head-to-tail cyclization, and a linear amino acid sequence.

Ricinus communis L. is a plant from the Euphorbiaceae family known for the presence of the protein ricin, an extremely toxic natural poison found in high amounts in the plant. Ricin can be toxic by ingestion, inhalation, or injection [82,83]. Recently, three new peptides, designated $R$. communis L. biomarkers (RCB) 1-3, were identified in the plant seeds. Those peptides comprise homologous sequences of 19 (RCB-1) or 18 (RCB-2 and RCB-3) 
amino acid residues, including four cysteine moieties and disulfide bonds [82]. Thus, RCB-1 consists of 19 amino acids and has two disulfide bonds, and the structure was determined to be (-Ala-Arg-Cys-Cys-Leu-Val-Met-Pro-Val-Pro-Pro-Phe-Ala-Cys-ValLys-Phe-Cys-Ser-) [83]. It was synthesized by SPPS with the assistance of microwave heating during the deprotection and coupling reaction steps, and then subjected to oxidative folding. Additionally, the three-dimensional structure of RCB-1 was determined [82]. RCB-2 contains 18 amino acids and two disulfide bonds, and the sequence was determined to be (-Ala-Arg-Cys-Cys-LeuVal-Met-Pro-Val-Pro-Pro-Phe-Ala-Cys-Val-Lys-Phe-Cys-). The peptide RCB-3 also has two disulfide bonds and has the sequence (-Ala-Arg-Cys-Cys-Leu-Val-Leu-Pro-Val-Pro-Pro-Phe-Ala-Cys-ValLys-Phe-Cys-) [83]. Due to their similarity to the Ib-AMP peptide family, it was suggested that the function of these RCB peptides might be related to plant defence, playing a role in seed protection, although further investigations are still suggested $[82,83]$. The genus Euphorbia also contains peptides. A molecule identified as a peptide derivative, aurentiamide acetate, compound 4 , was isolated from the roots of Euphorbia fischeriana Steudel [84]. As mentioned previously, this compound was also found in the aerial parts of C. hieronymi Griseb [22].

\section{Biological Activities}

\section{Cytotoxicity}

Cytotoxicity is a well-documented activity for orbitides. As found in the literature, some orbitides are cytotoxic, and others are demonstrated to be nontoxic to the cells. This different behavior may be related to their conformation, their sequence, the presence of charges, the number of amino acid residues, and the type of tumor cells involved. Thus, the mechanism of action needs to be further investigated. The orbitide [1-9-NaC]-crourorb A1 (2) isolated from the latex of $C$. urucurana Baill. was evaluated against six human cancer cell lines, namely, 786-0 (human kidney carcinoma), HT-29 (human colon carcinoma), MCF-7 (breast adenocarcinoma), NCl-ADR/RES (ovary adenocarcinoma, multidrug-resistance phenotype), PC-03 (human prostate carcinoma), and Hep-G2 (hepatocellular carcinoma). Compound 2 demonstrated selective inhibition against $\mathrm{NCl}-\mathrm{ADR} / \mathrm{RES}$ cells $\left(\mathrm{Gl}_{50}=4.8 \mu \mathrm{M}\right)$ although according to the authors, further studies are necessary to determine the effects on nontumour cells [36]. The orbitide ribifolin (9), isolated from the aerial parts of J. ribifolia (Pohl) Baill., and its synthetic linear analogue were assessed for their cytotoxicity towards human embryonic kidney cells (HEK293T). No cytotoxicity was observed; normal growth occurred in the tested concentration range $(0.001-100 \mu \mathrm{M})[25]$. Cytotoxicity testing of curcacyclines, isolated from J. curcas L., demonstrated that curcacycline A (6) presented low toxicity to OVCAR 3 (ovarium cancer cells) with an $\mathrm{IC}_{50}$ of $945 \mu \mathrm{M}$, while no effect was found on Colo205 (human colon cancer cells). Curcacycline B (7) did not demonstrate any effect on either cell line. Additionally, they were evaluated in a brine shrimp cytotoxicity assay, and curcacycline A (6) and $B(7)$ showed $L_{50}$ values of $65.07 \mu \mathrm{M}$ and $18.35 \mu \mathrm{M}$, respectively [76].

\section{Antimalarial}

The orbitide ribifolin (9) and its linear synthetic analogue were evaluated for antimalarial activity. Ribifolin (9) demonstrated moderate activity with an $\mathrm{IC}_{50}$ of $42 \mu \mathrm{M}$ against the Plasmodium falciparum 3D7 strain, while the linear analogue was inactive $\left(\mathrm{IC}_{50}=\right.$ $519 \mu \mathrm{M})$, providing evidence that cyclization is important for the growth inhibitory activity against $P$. falciparum [25]. The pohlianins, isolated from J. pohliana ssp. molissima, were also evaluated for antimalarial activity, and moderate inhibition was obtained for these compounds. Pohlianin A (12) and B (13) had IC 50 values of $57 \mu \mathrm{M}$ and $25 \mu \mathrm{M}$, respectively. Pohlianin $C(14)$ showed an $I C_{50}$ of $16 \mu \mathrm{M}$ and was the most potent among the pohlianins [26]. The three chevalierins A (15), B (16), and C (17), obtained from J. chevalieri, were examined for antiproliferative activity against $P$. falciparum, but only chevalierin A (15) showed antimalarial activity, with an $\mathrm{IC}_{50}$ of $8.9 \mu \mathrm{M}$ [34]. The mahafacyclins, obtained from J. mahafalensis Jum. \& H. Perrier [33,79], were evaluated for antimalarial activity. Mahafacyclin A (20) presented a moderate antimalarial activity with an $\mathrm{IC}_{50}$ value of $16 \mu \mathrm{M}$ [79]. Mahafacyclin B (21) was the most potent and possessed an $\mathrm{IC}_{50}$ of $2.2 \mu \mathrm{M}$ P. falciparum [33]. Integerrimides $A(24)$ and $B(25)$, from the latex of J. integerrima Jacq., were evaluated in antimalarial assays but demonstrated to be inactive at test concentrations of $12.8 \mu \mathrm{M}$ and $13.0 \mu \mathrm{M}$, respectively [80]. Jatrophidin I (8) was also inactive in antimalarial assays [28].

\section{Immunosuppressive}

Autoimmune diseases can be classified as organ-specific or as systemic. On a molecular level, autoreactive T cells play an important role in disease progression [85]. The orbitide curcacycline A (6), isolated from J. curcas L., showed a moderate dose-dependent inhibition of human $T$ cell proliferation, although direct cytotoxic effects could not be observed [29]. Also, an immunologically active peptide, labaditin, was isolated from the latex of J. multifida $\mathrm{L}$. [32]. Usually, the immunosuppressive activity of orbitides is characterized by weak affinity to their molecular target, calcinerium. Other members of the orbitide famil,y such as cyclolinopeptides, cycloleonurinins, and hymenistatins, also exhibited potential immunosuppressive activity [85].

\section{Enzymatic Evaluation}

Jatrophidin I (8), isolated from J. curcas L., showed inhibitory activity in a fluorimetric protease inhibition assay using pepsin as a molecular model for aspartic protease inhibition. Its $\mathrm{IC}_{50}$ value was $0.88 \mu \mathrm{M}$, although it did not inhibit the serine protease subtilisin, thus suggesting a selective inhibition for aspartic proteases [28]. According to the authors, the structure of curcacycline B (7) was suggested to be a PPlase substrate. PPlase assays using human cyclophilin B, based on an $\alpha$-chymotrypsin-rotamase coupled enzymatic experiment, were carried out to determine if curcacycline $B$ (7) could bind human cyclophilin B. Curcacycline B (7) was shown to enhance the rotamase activity of human cyclophilin B. PPlase assays using human cyclophilin B were carried out to determine if curcacycline B (7) could bind the human cyclophilin B. In the absence of cyclophilin B, curcacycline B (7) had no effect on $\alpha$-chymotrypsin activity, although when the experiment was carried out 
in the presence of cyclophilin B, it enhanced the PPlase activity of cyclophilin B by $60 \%$ at $30 \mu \mathrm{M}$.

\section{Antibacterial and antifungal}

The search for new classes of antibiotics, such as AMPs, has become even more relevant as the resistance of bacteria has reached higher levels worldwide. Investigation of the antibacterial activity of labaditin (18), isolated from J. multifida L., demonstrated a reduction of viability in gram-positive bacteria (Streptococcus mutans), while its linear analogue is not active, thus demonstrating that cyclization might contribute to the antibacterial activity. No effects were observed in gram-negative bacteria (Aggregatibacter actinomycetemcomitans) for concentrations ranging up to $100 \mathrm{mM}$ [86]. Labaditin (18) and its linear analogue were also evaluated against Staphylococcus aureus. It was shown that the cyclic compound (18) was highly effective against $S$. aureus, with no bacterial growth at a concentration as low as $0.23 \mathrm{mM}$. On the other hand, the linear analogue required concentrations above $28.6 \mathrm{mM}$ to be active. According to Barbosa and co-authors [87], the antibacterial activity of labaditin (18) was related to its inducing leakage in the cell membrane. Leakage occurs with the self-assembly of labatidin (18) into a nanotube owing to its preserved secondary structure in the membrane. Additionally, this mode of action may represent a promising step towards the design of a new class of antibiotics. The screening of curcacycline $A(6)$ for antibiotic activity was done against five strains, Bacillus subtilis, S. aureus, Escherichia coli, Pseudomonas aeruginosa, and Candida albicans, using the paper disk ( $6 \mathrm{~mm}$ of diameter) diffusion method at a concentration of $1.3 \mathrm{mM}$. Curcacycline $A(6)$ inhibited the growth of $B$. subtilis and $P$. aeruginosa with inhibition zones of $(10.3 \pm 0.4 \mathrm{~mm})$ and $(8.3 \pm 0.8 \mathrm{~mm})$, respectively. Although the mechanistic action of curcacyline A (6) still remains unclear, the antibacterial activity of cyclic peptides might be related to their ability to cross membranes and their higher affinity to bind with some proteins [76]. The orbitides integerrimides A (24) and B (25), obtained from the latex of J. integerrima Jacq., were evaluated for antifungal assays, although they were demonstrated to be inactive at concentrations of $64.1 \mu \mathrm{M}$ and $65.3 \mu \mathrm{M}$, respectively [80]. In addition, jatrophidin I (8) was inactive in antifungal assays [28]. The antibacterial and antifungal activity of peptide RCB-1, isolated from $R$. communis L., was tested against human and plant pathogens. Different concentrations of RCB-1, ranging from 160 to $0.625 \mu \mathrm{M}$, were used. The compound RCB-1 was found to be active against only $P$. aeruginosa, although it was tested against a set of human pathogens (E. coli, S. aureus, and C. albicans) and plant pathogens (Erwinia carotovora, Erwinia amylovora, and Aspergillus fumigatus) [82].

\section{Other Families as Orbitide Sources}

Plants in different angiosperm families are notorious for accumulating peptides, primarily cyclic peptides [7]. According to the literature, in addition to being found in the Euphorbiaceae family, orbitides can also be isolated from at least eight other plant families, including Annonaceae, Caryophyllaceae, Lamiaceae, Linaceae, Phytolaccaceae, Rutaceae, Schisandraceae, and Verbenaceae $[17,18]$.
In fact, the orbitides can be isolated not only from plant latex but also from seeds, leaves, roots, twigs, and stem bark. The Rutaceae family is commonly known as the citrus family, which is also the most economically important genus. Studies on Citrus species [88-91] led to the isolation of orbitides, and they also might be found in the Zanthoxylum [92, 93], Evodia [94], and Clausena genera [95, 96]. Recently, in 2016, the orbitide named [1-8-NoC]-zanriorb A1 was isolated from the leaves of Zanthoxylum riedelianum Engl. (Rutaceae) [93]. The proposed orbitide name of this compound followed the systematic nomenclature recently suggested by Shim and co-authors [21]. This compound induced cell death by apoptosis in Jukart leukemia T cells with an $\mathrm{IC}_{50}$ of $218 \mathrm{nM}$ [93].

The Linaceae family is also a good source of orbitides. In 1959, the first orbitide, a cyclic nonapeptide from the flaxseed oil of Linum usitatissimum L. (Linaceae), was discovered by Kaufman and Tobschirble and named cyclolinopeptide A, cyclo(-Ile-LeuVal-Pro-Pro-Phe-Phe-Leu-Ile-) [97]. This cyclic nonapeptide exhibits several biological activities, and later on many additional cyclic peptides were isolated from linseed (cyclolinopeptide B-E and cyclolinopeptide F-I) $[98,99]$. Actually, the cyclolinopeptides are assigned in the literature as significant compounds found in flaxseed, but like many other orbitides, the role of these molecules in the plants remains unknown [100]. The Annonaceae family comprises approximately 130 genera, but most of the orbitides documented in the literature are isolated from the genus Annona (Annona squamosa, Annona cherimola, Annona glauca) [101-103]. Caryophyllaceae is a family of flowering plants with 81 genera, commonly called the pink family. Some plants belonging to the Caryophyllaceae family contain cyclic peptides, and they are most commonly found in the genera Drymaria [104], Dianthus [105], Pseudostellaria [106-108], Stellaria [109-111], and Vaccaria [112].

In summary, more than 100 orbitides with various bioactivities have been discovered, and this number continues to grow as natural products remain an important source of bioactive compounds over the years [53]. Additionally, other classes of peptides might emerge with new bioactivities and novel applications, thus attracting the attention of many researchers worldwide.

\section{Elucidation Techniques and Chemical Synthesis}

Orbitide structures are mainly identified by two techniques, NMR and MS, which are very well established in this research field. In NMR spectroscopy, each resonance must be associated with a specific nucleus in the investigated molecule, a process called assignment. Thus, the data are assigned by one-dimensional (1D) ${ }^{1} \mathrm{H},{ }^{13} \mathrm{C}$, and ${ }^{15} \mathrm{~N}$ and two-dimensional (2D) techniques such as COSY, TOCSY, NOESY, and ROESY (rotating frame Overhauser effect spectroscopy) NMR. Several overlaps may occur in ${ }^{1} \mathrm{H}$ and ${ }^{13} \mathrm{C}$ NMR spectra due to the similarity of the chemical shifts from different amino acid residues, which is the reason 2D NMR techniques became very suitable for structure determination [51, $113,114]$. In general, assignment can be done using homonuclear spectra in two steps: a) the sequential assignment of the amino acids in the peptide sequence and b) the assignment of the amino acid side chains [115]. 
Using TOCSY and COSY, it is possible to establish the identification of certain amino acid spin systems, with a characteristic pattern of cross signals. For example, Gly is the only residue in which two protons interact with the amide proton. Val, Leu, and Ile residues can be recognized by their two methyl groups, which give a characteristic row of double signals. In contrast, His, Trp, Tyr, and Phe residues are difficult to distinguish because $\mathrm{H} \alpha$ interacts with two methylene protons that do not show any J coupling to any of the ring protons (more than three bonds removed). Therefore, these residues are also difficult to distinguish from Asp, Asn, Cys, and Ser residues $[115,116]$. The next step in the assignment procedure concerns the identification of the sequence-specific position of each amino acid by a NOESY experiment. Briefly, the spectra obtained through this experiment are used to sequentially connect the spin systems. The connection of an amino acid in the sequence (i) to its following one $(i+1)$ can be observed in the NOESY because the distance of the amide proton of $(i+1)$ to the $\mathrm{H} \alpha, \mathrm{H} \beta$, or $\mathrm{H}$ y protons of (i) is frequently smaller than $5 \AA$. An exception is proline residues, which have no amide proton and for which no $\mathrm{HN}$ (i)- $\mathrm{H} \alpha(\mathrm{i}-1)$ cross signal can be observed. However, if the proline (i) is in its trans conformation, sequential $\mathrm{HN}(\mathrm{i}-1)-\mathrm{H} \delta(\mathrm{i})$ and $\mathrm{H} \alpha(\mathrm{i}-1)-$ $\mathrm{H} \delta(\mathrm{i})$ cross signals can be observed [116].

MS measures the mass-to-charge ratio $(\mathrm{m} / \mathrm{z})$ of gas-phase ions and is important for the accurate mass determination and characterization of peptides, only requiring small amounts of the compounds [117]. As it should be performed in the positive mode, it shows the protonated molecule $\mathrm{MH}^{+}$and frequently some adduct ions $[\mathrm{M}+\mathrm{Na}]^{+}$or $[\mathrm{M}+\mathrm{K}]^{+}$in the MS spectrum. The most used method for the ionization of orbitides is electrospray ionization (ESI). ESI is a solution technique used in conjunction with mass analyzers such as tandem mass spectrometry. MS is very sensitive and does not require peptides to be purified. Finally, the MS data must be consistent with the amino acid sequence derived from the NMR experiments. It was noticed that peptide amino acid sequences are typically reported in the literature in the order in which they occur in MS/MS fragmentation [21]. In addition, using NMR studies and X-ray crystallography, it is possible to assign the $3 \mathrm{D}$ structures of the cyclic peptides, thus providing more detailed information on the peptide structure $[51,113]$. NMR has the advantage that it can be done in solution and has proven to be a robust and widely applied technique [113]. In addition, crystallography gives the static structure of the molecule but requires the production of crystals, which are not often easily obtained in orbitides. Finally, the structures of orbitides have been proposed based on extensive 2D NMR investigation and HRMS [51].

The accessibility of orbitides by chemical synthesis has facilitated studies of their mechanism and activities, usually once just a few milligrams are obtained from the natural sources. The synthesis of cyclic peptides can occur in two different ways, in solution (classical synthesis) or in the presence of a polymeric support. The latter method is known as SPPS. SPPS is the most commonly used strategy due to its practicality, its higher speed, and the possibility of automation [114]. It is well established and applicable to any peptide synthesis. Thus, SPPS is considered a useful tool that can be applied to obtain cyclic peptide libraries and assist in biological assays, especially in vivo assays, which usually require higher amounts of compounds. Cyclic peptides differ from linear pep- tides in that their backbones have one additional peptide bond that joins the $\mathrm{N}$ - and $\mathrm{C}$-terminal to make a circular backbone [6]. The cyclization of linear peptides can be achieved in different ways, including head-to-tail, side chain-to-side chain, or terminus-to-side chain linkages, and, as was mentioned before, the orbitides are obtained through head-to-tail cyclization [118]. The synthesis of peptides containing a cyclic backbone is achieved by SPPS based on the 9-fluorenylmethoxycarbonyl (Fmoc) amino protection strategy of an acyclic (linear) precursor followed by an intramolecular reaction linking the $\mathrm{C}$ - and $\mathrm{N}$-termini. Thus, the linear chain is cyclized via amide bond formation [119]. SPPS was first developed by Merrifield $[120,121]$ and still remains an efficient strategy to obtain peptide libraries with chemodiversity. Furthermore, this technique provided great improvement in the drug discovery of peptide mimetics, especially ones involving changes in the backbones of novel molecules containing unnatural amino acids, mutations, and chemical modifications, which might help to drive their application as drug scaffolds.

\section{Conclusions}

In the current review, we have demonstrated that natural products play an important role in pharmaceutical and biological research, in which peptide-based drugs have a prominent place due to their chemical versatility, stability, and specificity. Although the description of plant-derived cyclic peptides has increased in recent years, the mechanisms of action of only a limited number of compounds have been reported. Additionally, despite the increasing number of compounds over the years, it has become clear that orbitides are still underexplored. Many cyclic peptides found in Euphorbiaceae and other plant families await discovery and further investigation. In addition, according to the literature, only the Jatropha and Croton genera have been documented as sources of orbitides in the Euphorbiaceae family. As demonstrated, there are still many species that have received little to no attention. Lastly, to address the disarray of orbitides nomenclature, which has been classified three times in the past few years, much effort was devoted by researchers and improvement was obtained in the classification and numbering of orbitides, highlighting the importance of this class of compounds in higher plants.

\section{Supporting information}

A table showing additional information on orbitide sequences, molecular weight, plant species, and synonyms is available as Supporting Information.

\section{Acknowledgements}

The authors are thankful for grant \#2015/09533-7 from the São Paulo Research Foundation (FAPESP) for the scholarship to S.D. R., the National Counsel of Technological and Scientific Development (CNPq) for grant \#162855/2015-0 for the scholarship to M. E. F.P., and SISBIOTACNPq-FAPESP for grant \#2010/52327-5 and grant \#2013/07600-3 for financial support.

Conflict of Interest

The authors declare no conflicts of interest. 


\section{References}

[1] Newman DJ, Cragg GM. Natural products as sources of new drugs from 1981 to 2014. J Nat Prod 2016; 79: 629-661

[2] Zasloff M. Antimicrobial peptides of multicellular organisms. Nature 2002; 415: 389-395

[3] Goransson U, Burman R, Gunasekera S, Stromstedt AA, Rosengren KJ. Circular proteins from plants and fungi. J Biol Chem 2012; 287: 2700127006

[4] Maqueda M, Sanchez-Hidalgo M, Fernandez M, Montalban-Lopez M, Valdivia E, Martinez-Bueno M. Genetic features of circular bacteriocins produced by Gram-positive bacteria. FEMS Microbiol Rev 2008; 32: 2-22

[5] Fusetani N, Matsunaga S. Bioactive sponge peptides. Chem Rev 1993; 93: $1793-1806$

[6] Craik DJ, Allewell NM. Thematic minireview series on circular proteins. J Biol Chem 2012; 287: 26999-27000

[7] Tan NH, Zhou J. Plant cyclopeptides. Chem Rev 2006; 106: 840-895

[8] Cragg GM, Newman DJ. Natural products: a continuing source of novel drug leads. Biochim Biophys Acta 2013; 1830: 3670-3695

[9] Craik DJ, Daly NL, Bond T, Waine C. Plant cyclotides: A unique family of cyclic and knotted proteins that defines the cyclic cystine knot structural motif. J Mol Biol 1999; 294: 1327-1336

[10] Gruber CW, Elliott AG, Ireland DC, Delprete PG, Dessein S, Goransson U, Trabi M, Wang CK, Kinghorn AB, Robbrecht E, Craik DJ. Distribution and evolution of circular miniproteins in flowering plants. Plant Cell 2008; 20: 2471-2483

[11] Burman R, Yeshak MY, Larsson S, Craik DJ, Rosengren KJ, Goransson U. Distribution of circular proteins in plants: large-scale mapping of cyclotides in the Violaceae. Front Plant Sci 2015; 6: 1-12

[12] Ravipati AS, Poth AG, Troeira Henriques S, Bhandari M, Huang YH, Nino J, Colgrave ML, Craik DJ. Understanding the diversity and distribution of cyclotides from plants of varied genetic origin. J Nat Prod 2017; 80: 1522-1530

[13] Sabandar CW, Ahmat N, Jaafar FM, Sahidin I. Medicinal property, phytochemistry and pharmacology of several Jatropha species (Euphorbiaceae): a review. Phytochemistry 2013; 85: 7-29

[14] Birk Y, Gertler A, Khalef S. A pure trypsin inhibitor from soya beans. Biochem J 1963; 87: 281-284

[15] Henriques ST, Craik D]. Cyclotides as templates in drug design. Drug Discov Today 2010; 15: 57-64

[16] Mahatmanto T. Review seed biopharmaceutical cyclic peptides: From discovery to applications. Biopolymers 2015; 104: 804-814

[17] Arnison PG, Bibb M], Bierbaum G, Bowers AA, Bugni TS, Bulaj G, Camarero JA, Campopiano DJ, Challis GL, Clardy J, Cotter PD, Craik DJ, Dawson M, Dittmann E, Donadio S, Dorrestein PC, Entian KD, Fischbach MA, Garavelli JS, Goransson U, Gruber CW, Haft DH, Hemscheidt TK, Hertweck C, Hill C, Horswill AR, Jaspars M, Kelly WL, Klinman JP, Kuipers OP, Link AJ, Liu W, Marahiel MA, Mitchell DA, Moll GN, Moore BS, Muller R, Nair SK, Nes IF, Norris GE, Olivera BM, Onaka H, Patchett ML, Piel J, Reaney MJ, Rebuffat S, Ross RP, Sahl HG, Schmidt EW, Selsted ME, Severinov K, Shen B, Sivonen K, Smith L, Stein T, Sussmuth RD, Tagg JR, Tang GL, Truman AW, Vederas JC, Walsh CT, Walton JD, Wenzel SC, Willey JM, van der Donk WA. Ribosomally synthesized and post-translationally modified peptide natural products: overview and recommendations for a universal nomenclature. Nat Prod Rep 2013; 30: 108-160

[18] Picchi DG, Altei WF, Saito MS, Bolzani VS, Cilli EM. Peptídeos cíclcicos de biomassa vegetal: características, diversidade, biossíntese e atividade biológicas. Quim Nova 2009; 32: 1262-1277

[19] Craik DJ, Fairlie DP, Liras S, Price D. The future of peptide-based drugs. Chem Biol Drug Des 2013; 81: 136-147

[20] Craik D], Shim YY, Goransson U, Moss GP, Tan N, Jadhav PD, Shen J, Reaney MJ. Nomenclature of homodetic cyclic peptides produced from ribosomal precursors: An IUPAC task group interim report. Biopolymers 2016; 106: 917-924

[21] Shim YY, Young LW, Arnison PG, Gilding E, Reaney MJ. Proposed systematic nomenclature for orbitides. J Nat Prod 2015; 78: 645-652

[22] Catalan CAN, Heluani CS, Kotowicz C, Gedris TE, Herz W. A linear sesterterpene, two squalene derivatives and two peptide derivatives from Croton hieronymi. Phytochemistry 2003; 64: 625-629

[23] Salatino A, Salatino MLF, Negri G. Traditional uses, chemistry and pharmacology of Croton species (Euphorbiaceae). J Braz Chem Soc 2007; 18 : $11-33$

[24] Seigler DS. Phytochemistry and systematics of Euphorbiaceae. Ann Mo Bot Gard 1994; 81: 380-401

[25] Pinto ME, Batista JM], Koehbach J, Gaur P, Sharma A, Nakabashi M, Cill EM, Giesel GM, Verli H, Gruber CW, Blanch EW, Tavares JF, da Silva MS, Garcia CR, Bolzani VS. Ribifolin, an orbitide from Jatropha ribifolia, and its potential antimalarial activity. J Nat Prod 2015; 78: 374-380

[26] Auvin-Guette C, Baraguey C, Blond A, Xavier HS, Pousset JL, Bodo B. Pohlianins A, B and C, cyclic peptides from the latex of Jatropha pohliana ssp. molissima. Tetrahedron 1999; 55: 11495-11510

[27] Van den Berg AJJ, Horsten SFA], Van den Bosch JJK, Beukelman C], Kroes BH, Leeflang BR, Labadie RP. Podacycline A and B, two cyclic peptides in the latex of Jatropha podagrica. Phytochemistry 1996; 42: 129-133

[28] Altei WF, Picchi DG, Abissi BM, Giesel GM, Flausino O], Reboud-Ravaux M, Verli H, Crusca EJ, Silveira ER, Cilli EM, Bolzani VS. Jatrophidin I, a cyclic peptide from Brazilian Jatropha curcas L.: isolation, characterization, conformational studies and biological activity. Phytochemistry 2014; 107: 91-96

[29] Van den Berg AJ], Horsten SFA], Van den Bosch JJK, Kroes BH, Beukelman C], Leeflang BR, Labadie RP. Curcacycline A - a novel cyclic octapeptide isolated from the latex of Jatropha curcas L. FEBS Lett 1995; 358: 215-218

[30] Auvin C, Baraguey C, Blond A, Lezenven F, Pousset JL, Bodo B. Curcacycline $\mathrm{B}$, a cyclic nonapeptide from Jatropha curcas enhancing rotamase activity of cyclophilin. Tetrahedron Lett 1997; 38: 2845-2848

[31] Auvin-Guette C, Baraguey C, Blond A, Pousset JL, Bodo B. Cyclogossine B, a cyclic octapeptide from Jatropha gossypifolia. J Nat Prod 1997; 60: $1155-1157$

[32] Kosasi S, Van der Sluis WG, Boelens R, Hart LA, Labadie RP. Labaditin, a novel cyclic decapeptide from the latex of Jatropha multifida L. (Euphorbiaceae). FEBS Lett 1989; 256: 91-96

[33] Baraguey C, Blond A, Cavelier F, Pousset JL, Bodo B, Auvin-Guette C. Isolation, structure and synthesis of mahafacyclin $B$, a cyclic heptapeptide from the latex of Jatropha mahafalensis. J Chem Soc 2001: 2098-2103

[34] Baraguey C, Auvin-Guette C, Blond A, Cavelier F, Lezenven F, Pousset JL, Bodo B. Isolation, structure and synthesis of chevalierins A, B and C, cyclic peptides from the latex of Jatropha chevalieri. J Chem Soc 1998: 3033-3039

[35] Mehmood R, Malik A. Isolation and characterization of crotosparsamide, a new cyclic nonapeptide from Croton sparsiflorus. Nat Prod Commun 2010; 5: 1885-1888

[36] Candido-Bacani PM, Figueiredo PO, Matos MF, Garcez FR, Garcez WS Cytotoxic orbitide from the latex of Croton urucurana. J Nat Prod 2015; 78: $2754-2760$

[37] Quintyne-Walcott S, Maxwell AR, Reynolds WF. Crotogossamide, a cyclic nonapeptide from the latex of Croton gossypifolius. J Nat Prod 2007; 70: 1374-1376

[38] Poth AG, Chan LY, Craik D]. Cyclotides as grafting frameworks for protein engineering and drug design applications. Biopolymers 2013; 100: 480491

[39] Craik DJ, Swedberg JE, Mylne JS, Cemazar M. Cyclotides as a basis for drug design. Expert Opin Drug Discov 2012; 7: 179-194

[40] Silva SI, Oliveira AFM, Negri G, Salatino A. Seed oils of Euphorbiaceae from the Caatinga, a Brazilian tropical dry forest. Biomass Bioenerg 2014; 69: 124-134 
[41] Secco RS, Cordeiro I, Senna-Vale L, Sales MF, Lima LR, Medeiros D, Haiad BS, Oliveira AS, Caruzo MBR, Carneiro-Torres D, Bigio NC. An overview of recent taxonomic studies on Euphorbiaceae s.l. in Brazil. Rodriguesia 2012; 63: 227-242

[42] Mwine JT, Van Damme P. Why do Euphorbiaceae tick as medicinal plants? A review of Euphorbiaceae family and its medicinal features. Jed Plant Res 2011; 5: 652-662

[43] Devappa RK, Makkar HP, Becker K. Jatropha toxicity - a review. J Toxicol Environ Health B Crit Rev 2010; 13: 476-507

[44] The Plant List. Version 1.1. 2013. Available at http://www.theplantlist. org/1.1/cite/. Accessed April 22, 2017

[45] Williamson EM, Hooper M. Ayurvedic Medicine. In: Williamson EM, ed. Major Herbs of Ayurveda. Edinburgh: Churchill Livingstone; 2002: 321325

[46] Lai XZ, Yang YB, Shan XL. The investigation of Euphorbiaceous medicinal plants in southern China. Econ Bot 2004; 58: 307-320

[47] Abdelgadir HA, Van Staden J. Ethnobotany, ethnopharmacology and toxicity of Jatropha curcas L. (Euphorbiaceae): a review. S Afr J Bot 2013; 88: 204-218

[48] Rizk AFM. The chemical constituents and economic plants of the Euphorbiaceae. Bot J Linn Soc 1986; 94: 293-326

[49] Refahy LAG. Study on flavonoids and triterpenoids content of some Euphorbiaceae plants. J Life Sci 2011; 5: 100-107

[50] Abdulladzhanova NG, Mavlyanov SM, Dalimov DN. Polyphenols of certain plants of the Euphorbiaceae family. Chem Nat Compd 2003; 39: 399-400

[51] Pomilio AB, Battista ME, Vitale AA. Naturally-occurring cyclopeptides: structures and bioactivity. Curr Org Chem 2006; 10: 2075-2121

[52] Ortega MA, Van der Donk WA. New insights into the biosynthetic logic of ribosomally synthesized and post-translationally modified peptide natural products. Cell Chem Biol 2016; 23: 31-44

[53] Conibear AC, Craik D]. The chemistry and biology of theta defensins. Angew Chem Int Ed Engl 2014; 53: 10612-10623

[54] Barber C], Pujara PT, Reed DW, Chiwocha S, Zhang H, Covello PS. The two-step biosynthesis of cyclic peptides from linear precursors in a member of the plant family Caryophyllaceae involves cyclization by a serine protease-like enzyme. J Biol Chem 2013; 288: 12500-12510

[55] Yang X, Van der Donk WA. Ribosomally synthesized and post-translationally modified peptide natural products: new insights into the role of leader and core peptides during biosynthesis. Chem Eur J 2013; 19: 7662-7677

[56] Chekan JR, Estrada P, Covello PS, Nair SK. Characterization of the macrocyclase involved in the biosynthesis of RiPP cyclic peptides in plants. Proc Natl Acad Sci U S A 2017; 114: 6551-6556

[57] Condie JA, Nowak G, Reed DW, Balsevich J], Reaney MJ, Arnison PG, Covello PS. The biosynthesis of Caryophyllaceae-like cyclic peptides in Saponaria vaccaria L. from DNA-encoded precursors. Plant J 2011; 67: 682-690

[58] Sato S, Hirakawa H, Isobe S, Fukai E, Watanabe A, Kato M, Kawashima K, Minami C, Muraki A, Nakazaki N, Takahashi C, Nakayama S, Kishida Y, Kohara M, Yamada M, Tsuruoka H, Sasamoto S, Tabata S, Aizu T, Toyoda A, Shin-i T, Minakuchi Y, Kohara Y, Fujiyama A, Tsuchimoto S, Kajiyama S, Makigano E, Ohmido N, Shibagaki N, Cartagena JA, Wada N, Kohinata T, Atefeh A, Yuasa S, Matsunaga S, Fukui K. Sequence analysis of the genome of an oil-bearing tree, Jatropha curcas L. DNA Res 2011; 18: 65-76

[59] Ngadjui BT, Abegaz BM, Keumedjio F, Folefoc GN, Kapche GWF. Diterpenoids from the stem bark of Croton zambesicus. Phytochemistry 2002; 60: 345-349

[60] Ngadjui BT, Folefoc GG, Keumedjio F, Dongo E, Sondengam BL, Connolly JD. Crotonadiol, a labdane diterpenoid from the stem bark of Croton zambesicus. Phytochemistry 1999; 51: 171-174

[61] Block S, Baccelli C, Tinant B, Van Meervelt L, Rozenberg R, Jiwan JLH, Llabres G, Pauw-Gillet MC, Quetin-Leclercq J. Diterpenes from the leaves of Croton zambesicus. Phytochemistry 2004; 65: 1165-1171
[62] Vigor C, Fabre N, Fouraste I, Moulis C. Three clerodane diterpenoids from Croton eluteria Bennett. Phytochemistry 2001; 57: 1209-1212

[63] Gurgel LA, Sidrim J], Martins DT, Cechinel Filho V, Rao VS. In vitro antifungal activity of dragon's blood from Croton urucurana against dermatophytes. J Ethnopharmacol 2005; 97: 409-412

[64] Gupta D, Bleakley B, Gupta RK. Dragon's blood: botany, chemistry and therapeutic uses. J Ethnopharmacol 2008; 115: 361-380

[65] Sandoval M, Okuhama NN, Clark M, Angeles FM, Lao J, Bustamante S, Miller MJS. Sangre de grado Croton palanostigma induces apaptosis in human gatrointestinal cancer cells. J Ethnopharmacol 2002; 80: 121-129

[66] Rossi D, Bruni R, Bianchi N, Chiarabelli C, Gambari R, Medici A, Lista A, Paganetto $G$. Evaluation of the mutagenic, antimutagenic and antiproliferative potential of Croton lechleri (Muell. Arg.) latex. Phytomedicine 2003; 10: 139-144

[67] Froldi G, Zagotto G, Filippini R, Montopoli M, Dorigo P, Caparrotta L. Activity of sap from Croton lechleri on rat vascular and gastric smooth muscles. Phytomedicine 2009; 16: 768-775

[68] Lopes MI, Saffi ], Echeverrigaray S, Henriques JA, Salvador M. Mutagenic and antioxidant activities of Croton lechleri sap in biological systems. J Ethnopharmacol 2004; 95: 437-445

[69] Alonso-Castro AJ, Ortiz-Sanchez E, Dominguez F, Lopez-Toledo G Chavez M, Ortiz-Tello Ade J, Garcia-Carranca A. Antitumor effect of Croton lechleri Mull. Arg. (Euphorbiaceae). J Ethnopharmacol 2012; 140: 438-442

[70] Prasad DMR, Izam A, Khan MMR. Jatropha curcas: plant of medicinal benefits. J Med Plant Res 2012; 6: 2691-2699

[71] Sharma SK, Singh H. A review on pharmacological significance of genus Jatropha (Euphorbiaceae). Chin J Integr Med 2012; 18: 868-880

[72] Zhang XP, Zhang ML, Su XH, Huo CH, Gu YC, Shi QW. Chemical constituents of the plants from the genus Jatropha. Chem Biodivers 2009; 6: 2166-2183

[73] Oliveira JS, Leite PM, Souza LB, Mello VM, Silva EC, Rubim JC, Meneghetti SMP, Suarez PAZ. Characteristics and composition of Jatropha gossypiifolia and Jatropha curcas L. oils and application for biodiesel production. Biomass Bioenerg 2009; 33: 449-453

[74] Nath LK, Dutta SK. Extraction and purification of curcain, a protease from the latex of Jatropha curcas Linn. J Pharm Pharmacol 1991; 43: 111-114

[75] Insanu M, Dimaki C, Wilkins R, Brooker J, Van der Linde P, Kayser O. Rational use of Jatropha curcas L. in food and medicine: from toxicity problems to safe applications. Phytochem Rev 2013; 12: 107-119

[76] Insanu M, Anggadiredja J, Oliver K. Curcacycline A and B - new pharmacological insights to an old drug. Int J Appl Res Nat Prod 2012; 5: 26-34

[77] Horsten SFAJ, Van den Berg AJJ, Van den Bosch JJK, Leeflang BR, Labadie RP. Cyclogossine A: a novel cyclic heptapeptide isolated from the latex of Jatropha gossypifolia. Planta Med 1996; 62: 46-50

[78] Labadie RP. Immunomodulatory Compounds. In: Colgate SM, Molyneux RJ, eds. Bioactive natural Products: Detection, Isolation and structural Determination. Boca Raton: CRC Press; 1993: 279-317

[79] Baraguey C, Blond A, Correia I, Pousset JL, Bodo B, Auvin-Guette C. Mahafacyclin A, a cyclic heptapeptide from Jatropha mahafalensis exhibiting $\beta$-bulge conformation. Tetrahedron Lett 2000; 41: 325-329

[80] Mongkolvisut W, Sutthivaiyakit S, Leutbecher H, Mika S, Klaiber I, Moller W, Rosner H, Beifuss U, Conrad J. Integerrimides A and B, cyclic heptapeptides from the latex of Jatropha integerrima. J Nat Prod 2006; 69: 1435-1441

[81] Jucá TL, Monteiro-Moreira ACO, Moreira RA, Araújo CV, Lopes JLS, Moreno FBMB, Ramos MV. A new peptide from Jatropha curcas seeds: Unusual sequence and insights into its synthetic analogue that enhances proteolytic activity of papain. Process Biochem 2015; 50: 1434-1440

[82] Boldbaatar D, Gunasekera S, El-Seedi HR, Goransson U. Synthesis, structural characterization, and bioactivity of the stable peptide RCB-1 from Ricinus communis. J Nat Prod 2015; 78: 2545-2551 
[83] Ovenden SPB, Fredriksson SA, Bagas CK, Bergstrom T, Thomson SA, Nilsson C, Bourne DJ. De novo sequencing of RCB-1 to -3: peptide biomarkers from the castor bean plant Ricinus communis. Anal Chem 2009; 81: 3986-3996

[84] Uemura D, Sugiura K, Hirata Y. O-acetyl-N-(N'-benzoyl-L-phenilalanyl)L-Phenylalaninol. Isolation from Euphorbia fischeriana Steudel. Chem Lett 1975; 1: 537-538

[85] Thell K, Hellinger R, Schabbauer G, Gruber CW. Immunosuppressive peptides and their therapeutic applications. Drug Discov Today 2014; 19: 645-653

[86] Barbosa SC, Cilli EM, Dias LG, Stabeli RG, Ciancaglini P. Labaditin, a cyclic peptide with rich biotechnological potential: preliminary toxicological studies and structural changes in water and lipid membrane environment. Amino Acids 2011; 40: 135-144

[87] Barbosa SC, Nobre TM, Volpati D, Ciancaglini P, Cilli EM, Lorenzón NE, Oliveira ON jr. The importance of cyclic structure for labaditin on its antimicrobial activity against Staphylococcus aureus. Coll Surf B 2016; 148: $453-459$

[88] Matsubara Y, Yusa T, Sawabe A, Lizuka Y, Takekuma S, Yoshida Y. Structures of new cyclic peptides in young unshiu (Citrus unshiu MARCOV.), orange (Citrus sinenis Osbeck.) and Amanatsu (Citrus natsudaidai) peelings. Agric Biol Chem 1991; 55: 2923-2929

[89] Matsumoto T, Nishimura K, Takeya K. New cyclic peptides from Citrus medica var. sarcodactylis SWINGLE. Chem Pharm Bull 2002; 50: 857860

[90] Noh H], Hwang D, Lee ES, Hyun JW, Yi PH, Kim GS, Lee SE, Pang C, Park Y], Chung KH, Kim GD, Kim KH. Anti-inflammatory activity of a new cyclic peptide, citrusin $\mathrm{XI}$, isolated from the fruits of Citrus unshiu. J Ethnopharmacol 2015; 163: 106-112

[91] Morita H, Enomoto M, Hirasawa Y, lizuka T, Ogawa K, Kawahara N, Goda Y, Matsumoto T, Takeya K. Cyclonatsudamine A, a new vasodilator cyclic peptide from Citrus natsudaidai. Bioorg Med Chem Lett 2007; 17: $5410-5413$

[92] Ribeiro TAN, Silva LR, Junior PTS, Castro RN, Carvalho MG. A new cyclopeptide and other constituents from the leaves of Zanthoxylum rigidum Humb. \& Bonpl. ex Willd. (Rutaceae). Helv Chim Acta 2012; 95: 935939

[93] Beirigo PJS, Torquato HF, Santos CH, Carvalho MG, Castro RN, ParedesGamero E], Sousa PT], Jacinto M], Silva VC. [1-8-NalphaC]-Zanriorb A1, a proapoptotic orbitide from leaves of Zanthoxylum riedelianum. J Nat Prod 2016; 79: 1454-1458

[94] Eggleston DS, Baures PW, Peishoff CE, Kopple KD. Conformations of cyclic heptapeptides: crystal structure and computational studies of evolidine. J Am Chem Soc 1991; 113: 4410-4416

[95] Wang YS, He HP, Yang JH, Shen YM, Zhou J, Hao XJ. A new cyclopeptide from Clausena anisum-olens. Helv Chim Acta 2005; 88: 2345-2348

[96] Wang YS, He HP, Yang JH, Di YT, Tan NH, Hao XJ. Clausenain B, a phenylalanine-rich cyclic octapeptide from Clausena anisum-olens. J Braz Chem Soc 2009; 20: 478-481

[97] Kaufmann HP, Tobschirbel A. Über ein Oligopeptid aus Leinsamen. Chem Ber 1959; 92: 2805-2810

[98] Matsumoto T, Shishido A, Morita H, Itokawa H, Takeya K. Cyclolinopeptides F-I, cyclic peptides from linseed. Phytochemistry 2001; 57: 251-260

[99] Morita H, Shishido A, Matsumoto T, Itokawa H, Takeya K. Cyclolinopeptides B-E, new cyclic peptides from Linum usitatissimum. Tetrahedron 1999; 55: 967-976

[100] Shim YY, Gui B, Arnison PG, Wang Y, Reaney MJT. Flaxseed (Linum usitatissimum L.) bioactive compounds and peptide nomenclature: A review. Trends Food Sci Technol 2014; 38: 5-20
[101] Chao-Ming L, Ning-Hua T, Qing M, Hui-Lan Z, Xiao-Jiang H, Yu W, Jun Z. Cyclopeptide from the seeds of Annona squamosa. Phytochemistry 1997; 45: 521-523

[102] Wélé A, Zhang Y, Ndoye I, Brouard JP, Pousset JL, Bodo B. A cytotoxic cyclic heptapeptide from the seeds of Annona cherimola. J Nat Prod 2004; 67: 1577-1579

[103] Wélé A, Zhang Y, Dubost L, Pousset JL, Bodo B. Cyclic peptides from the seeds of Annona glauca and A. cherimola. Chem Pharm Bull 2006; 54: 690-692

[104] Ding Z, Zhou J, Tan N, Teng R. Two new cyclic peptides from Drymaria diandra. Planta Med 2000; 66: 386-388

[105] Hsieh PW, Chang FR, Wu CC, Wu KY, Li CM, Chen SL, Wu YC. New cytotoxic cyclic peptides and dianthramide from Dianthus superbus. J Nat Prod 2004; 67: 1522-1527

[106] Morita H, Kayashita T, Koichi T, Hideji I. Cyclic peptides from higher plants, part 15. Pseudostellarin $\mathrm{H}$, a new cyclic octapeptide from Pseudostellaria heterophylla. J Nat Prod 1995; 58: 943-947

[107] Morita H, Kayashita T, Kobata H, Gonda A, Takeya K, Itokawa H. Pseudostellarins A-C, new tyrosine inhibitory cyclic peptides from Pseudostellaria heterophylla. Tetrahedron 1994; 50: 6797-6804

[108] Morita H, Kayashita T, Kobata H, Gonda A, Takeya K, Itokawa H. Pseudostellarins D-F, new tyrosinase inhibitory cyclic peptides from Pseudostellaria heterophylla. Tetrahedron 1994; 50: 9975-9982

[109] Morita H, Shishido A, Kayashita T, Koichi T, Itokawa H. Cyclic peptides from higher plants. 39. Dichotomins F and G, cyclic peptides from Stellaria dichotoma var. lanceolata. J Nat Prod 1997; 60: 404-407

[110] Morita H, Kayashita T, Shimomura M, Takeya K, Itokawa H. Cyclic peptides from higher plants. 24. Yunnanin C, a novel cyclic heptapeptide from Stellaria yunnanensis. J Nat Prod 1996; 59: 280-282

[111] Morita H, Shishido A, Kayashita T, Shimomura M, Takeya K, Itokawa H. Two novel cyclic peptides, Yunnanins A and B from Stellaria yunnanenis. Chem Lett 1994; 1: 2415-2418

[112] Yun YS, Morita H, Takeya K, Itokawa H. Cyclic peptides from higher plants. 34. Segetalins $G$ and $H$, structures and estrogen-like activity of cyclic pentapeptides from Vaccaria segetalis. J Nat Prod 1997; 60: 216218

[113] Kaas Q, Craik DJ. NMR of plant proteins. Prog Nucl Magn Reson Spectrosc 2013; 71: 1-34

[114] Machado A, Liria CW, Proti PB, Remuzgo C, Miranda MTM. Chemical and enzymatic peptide synthesis: basic aspects and applications. Quim Nova 2004; 27: 781-789

[115] Wuthrich K. NMR Spectra of Proteins and nucleic Acids in Solution. In: Wuthrich K, ed. NMR of Proteins and nucleic Acids. New York: Wiley; 1986: $27-39$

[116] Bax A. Two-dimensional NMR and protein structures. Annu Rev Biochem 1989; 58: 223-256

[117] Han X, Aslanian A, Yates JR. Mass spectrometry for proteomics. Curr Opin Chem Biol 2008; 12: 483-490

[118] White AM, Craik DJ. Discovery and optimization of peptide macrocycles. Expert Opin Drug Discov 2016; 11: 1151-1163

[119] Cheneval O, Schroeder Cl, Durek T, Walsh P, Huang YH, Liras S, Price DA, Craik DJ. Fmoc-based synthesis of disulfide-rich cyclic peptides. J Org Chem 2014; 79: 5538-5544

[120] Merrifield RB. Solid phase peptide synthesis. I. The synthesis of a tetrapeptide. J Am Chem Soc 1963; 85: 2149-2154

[121] Merrifield RB. Solid-phase peptide synthesis. III. An improved synthesis of bradykinin. Biochemistry 1964; 3: 1385-1390 